\title{
Asesmen Multi Representasi Berbasis Keterampilan Abad Ke-21 pada Materi Gerak Lurus
}

\author{
Ellianawati, S. Mufiatunnikmah*, N. E. Setyaningsih, B. Subali \\ Jurusan Fisika, FMIPA Universitas Negeri Semarang, Indonesia \\ *email: siti_mufiatunnikmah@yahoo.co.id
}

Received: October $1^{\text {th }}, 2019$. Accepted: December $12^{\text {nd }}, 2019$. Published: Februari $29^{\text {th }}, 2020$

\begin{abstract}
Abstrak
Penelitian ini bertujuan untuk menentukan angka kualitas asesmen multi representasi berbasis abad ke-21 pada materi Gerak Lurus. Penelitian ini merupakan penelitian pengembangan (R\&D). Data dianalisis menggunakan uji validitas asesmen oleh ahli dan uji kualitas asesmen secara empiris untuk memperoleh angka kualitas berupa validitas, reliabilitas, taraf kesukaran, dan daya beda butir soal. Hasil analisis uji coba produk menunjukkan 58,33\% butir soal dinyatakan valid dan $41,67 \%$ butir soal dinyatakan tidak valid. Soal dinyatakan mempunyai reliabilitas yang sangat tinggi dengan nilai 0,877 . Proporsi taraf kesukaran soal yang diperoleh belum ideal yaitu sebesar 58,33\% soal berkategori sukar dan 41,67\% soal berkategori sedang/cukup. Daya beda soal berada pada presentase $8,34 \%$ soal berdaya beda baik, 22,22\% cukup, $58,33 \%$ jelek, dan 11,11\% sangat jelek. Hasil uji coba pemakaian diperoleh $69,44 \%$ butir soal dinyatakan valid dan $30,56 \%$ butir soal dinyatakan tidak valid. Soal dinyatakan mempunyai reliabilitas yang tinggi dengan nilai 0,879 . Proporsi taraf kesukaran soal yang diperoleh pada uji coba pemakaian juga belum ideal yaitu sebesar $56 \%$ soal berkategori sukar dan $44 \%$ soal berkategori sedang/cukup. Daya beda soal terdiri atas 32\% soal berdaya beda baik, $40 \%$ cukup, dan $28 \%$ jelek.
\end{abstract}




\begin{abstract}
This study aims to determine the quality figures of $21^{\text {st }}$ century-based multi-representation assessments on linear motion material. Type of this research is Research \& Development (R\&D). Data were analyzed using an assessment validity test by an expert and empirical assessment quality test to obtain quality figures in the form of validity, reliability, level of difficulty, and discrimination power. The results of the preliminary field testing analysis showed $58.33 \%$ items were declared valid and $41.67 \%$ items were declared invalid. Test items have very high reliability with a value of 0.877 . The proportion of the level of difficulty is not ideal, that is equal to $58.33 \%$ of questions categorized as difficult and $41.67 \%$ of questions categorized as sufficient. The discrimination power of the questions is $8.34 \%$ of the questions in a good category, $22.22 \%$ are sufficient, $58.33 \%$ are bad, and $11.11 \%$ are very bad. The result of main field testing, $69.44 \%$ items were declared valid and $30.56 \%$ items were declared invalid. Test items have high reliability with a value of 0.879 . The proportion of the level of difficulty obtained in the main field testing is also not ideal, which is $56 \%$ of the difficult category and $44 \%$ of the sufficient category. The discrimination power consist of $32 \%$ good, $40 \%$ were sufficient, and $28 \%$ were poor. (C2020PERJ
\end{abstract}

Keywords: Assessment; $21^{\text {st }}$ century skills; multi representation.

\section{PENDAHULUAN}

Perkembangan ilmu pengetahuan dan teknologi pada abad ke-21 memberikan tantangan baru di dunia pendidikan. Indonesia telah mengalami sepuluh pergantian kurikulum pendidikan yang salah satu tujuannya adalah untuk menjawab tantangan zaman. Kurikulum pendidikan yang kini dikembangkan di Indonesia adalah Kurikulum 2013 yang lebih mengintegrasikan Penguatan
Pendidikan Karakter (PPK), literasi, keterampilan abad 21, serta HOTS (Higher Order Thinking Skill).

Terdapat tiga mekanisme signifikan yang diperlukan untuk menanamkan keterampilan abad ke-21 seiring diberlakukannya kurikulum 2013. Pertama, masyarakat luas harus menyadari pentingnya keterampilan abad ke21 sebagai pendidikan masa kini. Ke dua, sekolah seharusnya memiliki desain baru untuk pembelajaran tentang bagaimana orang 
mempelajari pemrosesan informasi, penggunaan teknologi yang efektif, dan keterampilan abad ke-21 dalam konteks akademis. Ke tiga, pembuat kebijakan seharusnya berkontribusi dalam merumuskan kaidah penilaian yang dapat mengukur prestasi akademik dan keterampilan abad ke-21 (Osman et al., 2010). Sejalan dengan hal tersebut, Susianna (2014) telah melakukan penelitian tentang implementasi keterampilan abad 21 dalam Kurikulum 2013 kepada 350 guru dan dosen di berbagai daerah di Indonesia. Hasil analisis data menunjukkan bahwa hanya 35\% sampel yang dapat menjelaskan keterampilan abad 21; dan 17\% yang dapat merancang, mengakses, mengimplementasikan pembelajaran yang menekankan keterampilan abad 21 dengan benar. Hasil penelitian tersebut menunjukkan bahwa sistem pembelajaran dan kegiatan penilaian yang sesuai dengan keterampilan abad 21 perlu diperbaiki untuk mewujudkan pelaksanaan kegiatan pembelajaran yang berkualitas.

Asesmen merupakan komponen penting dalam dunia pendidikan. Peningkatan mutu pendidikan di Indonesia dapat dilakukan dengan meningkatkan kualitas sistem pembelajaran dan penilaian. Permendiknas Nomor 16 Tahun 2007 tentang Standar Kualifikasi Akademik dan Kompetensi Guru juga menyatakan bahwa guru mata pelajaran harus memiliki kompetensi, salah satunya adalah mengembangkan instrumen asesmen dan evalusi proses dan hasil belajar.

Asesmen untuk mengembangan pola pikir siswa merupakan tuntutan yang harus dipenuhi pada era global. Hal ini sejalan dengan Partnership of 21 $1^{\text {st }}$ Century Skills yang mengidentifikasi bahwa siswa pada abad ke-21 harus mampu mengembangkan keterampilan kompetitif yang berfokus pada pengembangan keterampilan berpikir tingkat tinggi (Higher Order Thinking Skills) (Hariyanto, 2014). Salah satu yang termasuk dalam keterampilan berpikir tingkat tinggi menurut Brookhart (2010) adalah berpikir kreatif (creative thinking). Keterampilan berpikir kreatif sangat penting dimiliki siswa, karena aspek kreatif merupakan salah satu tujuan dari pendidikan nasional.

Keterampilan berpikir kreatif atau berpikir divergen merupakan keterampilan dalam memberikan berbagai kemungkinan jawaban berdasarkan informasi yang diberikan (Munandar, 2012). Siswa harus memahami konsep secara mendalam untuk dapat memberikan berbagai kemungkinan jawaban. Oleh karena itu, penggunaan representasi yang kurang tepat akan menjadi halangan dalam memahami fisika (Gunel, 2006).

Hasil penelitian Sinaga (2014) menunjukkan pemahaman konsep fisika mahasiswa meningkat secara 
signifikan ketika mereka mampu menerjemahkan hubungan antara beberapa model representasi. Sunyono (2015) menyatakan bahwa belajar dengan multi representasi cocok untuk pembelajaran di kelas karena siswa dengan tingkat kemampuan rendah dapat bersaing dengan siswa berkemampuan menengah dan tinggi.

Rusilowati (2006) menyatakan penggunaan model representasi sebagai asesmen dapat menjadi solusi untuk mencari penyebab kesulitan belajar fisika. Akan tetapi, hasil observasi yang dilakukan di SMA Kota Semarang menunjukkan bahwa instrumen asesmen yang digunakan masih didominasi oleh satu representasi saja, yaitu matematis. Meskipun demikian, hasil penelitian Misel and E. Suwangsih (2016) menunjukkan bahwa kemampuan representasi matematis siswa masih berada dalam tingkatan rendah dengan persentase sebesar 23,7\%. Instrumen yang didominasi oleh salah satu representasi saja dirasa kurang dapat mengukur kemampuan riil siswa mengingat kecerdasaan yang dimiliki tiap individu sangat beragam.

Hasil penelitian lain tentang kemampuan representasi siswa menunjukkan kemampuan mempresentasikan format verbal ke dalam format verbal dan gambar memperoleh persentase tertinggi yaitu sebesar $85 \%$, sedangkan persentase terendah ditemukan pada

kemampuan mempresentasikan format diagram ke dalam format matematis yaitu 37\% (Leksana, 2017).

Materi Gerak Lurus merupakan salah satu materi fisika SMA kelas X. Gerak Lurus termasuk dalam bagian materi kinematika dalam satu dimensi. Siswa tidak cukup memahami materi kinematika pada salah satu bentuk representasi saja untuk penguasaan konsep kinematika, tetapi siswa harus mampu menguasai bermacammacam representasi (Purwanti, 2017). Namun, kemampuan representasi siswa di kota Batu dalam mengambil informasi dari berbagai representasi pada materi Gerak Lurus sangat rendah (Purwanti, 2016). Hal ini tidak menutup kemungkinan bahwa siswa di kota lain juga mengalami masalah yang sama dan belum teridentifikasi. Oleh karena itu, perlu dilakukan pengembangan asesmen multi representasi berbasis keterampilan abad ke-21 pada materi Gerak Lurus. Hasil penelitian ini dapat digunakan untuk mengidentifikasi kemampuan representasi dan kesulitan belajar siswa pada materi Gerak Lurus sehingga guru dapat menentukan langkah tepat untuk melakukan perbaikan.

\section{METODE}

Subjek penelitian ini yaitu siswa SMA yang telah mempelajari materi Gerak Lurus di SMA Negeri terakreditasi A. Desain penelitian 
ini adalah Research $\mathcal{E}$ Development yang mengacu desain penelitian (Sugiyono, 2017). Tahap-tahap dalam penelitian ini antara lain: (1) potensi dan masalah, (2) pengumpulan data, (3) desain produk, (4) validasi desain, (5) revisi desain, (6) uji coba produk, (7) revisi produk, (8) uji coba pemakaian, (9) revisi produk. Teknik analisis data berupa validitas instrumen asesmen oleh ahli dan kualitas butir soal yang meliputi validitas, reliabilitas, tingkat kesukaran dan daya beda.

\section{HASIL DAN PEMBAHASAN}

Produk yang dihasilkan dalam penelitian berupa instrumen asesmen multi representasi berbasis keterampilan abad ke-21 pada materi gerak lurus yang terdiri atas: 1) kisi-kisi soal, 2) naskah soal, 3) kunci jawaban, dan 4) pedoman penskoran.

\section{Validitas}

Data validasi instrumen asesmen multi representasi berbasis keterampilan abad ke-21 yang disusun diperoleh berdasarkan hasil penilaian instrumen oleh ahli, yaitu ahli dalam bidang keilmuan fisika dan instrumen asesmen. Berdasarkan validasi instrumen oleh ahli disimpulkan bahwa instrumen asesmen yang disusun dinyatakan sangat layak dan dapat diujikan pada uji coba produk dalam skala kecil dengan beberapa revisi dan saran perbaikan dari ahli.

Uji coba produk dilakukan dengan uji coba skala kecil di dua sekolah basis dengan jumlah 30 siswa. Uji coba produk bertujuan untuk mengetahui validitas, reliabilitas, taraf kesukaran, dan daya beda butir instrumen asesmen multi representasi berbasis keterampilan abad ke-21 yang disusun. Tindak lanjut terhadap hasil analisis validitas butir soal adalah menggunakan kembali butir soal yang dinyatakan valid pada uji coba pemakaian dan butir soal yang tidak valid diperbaiki untuk selanjutnya digunakan kembali pada uji coba pemakaian. Pada uji coba pemakaian dilakukan dengan uji coba skala besar di tiga SMA Negeri terakreditasi A dengan jumlah 60 siswa. Hasil analisis validitas pada uji coba produk dan pemakaian disajikan pada Tabel 1.

Berdasarkan persentase hasil analisis validitas butir soal yang dilakukan, terdapat peningkatan angka kualitas berupa validitas soal dari tahap uji coba produk ke tahap uji coba pemakaian. Hal ini disebabkan jumlah sampel uji coba produk lebih kecil dari uji coba pemakaian. Semakin besar ukuran sampel, maka semakin besar kemungkinan dapat mencerminkan populasi dan memberikan hasil yang semakin baik (Alwi, 2015).

Hasil analisis validitas dari uji coba produk dan uji coba pemakaian memiliki perbedaan. Berdasarkan hasil wawancara yang 
dilakukan, dapat disimpulkan beberapa hal, yaitu terdapat kategori soal yang tidak valid menjadi valid, perbaikan yang dilakukan sudah cukup baik terbukti dengan respon siswa yang merespon bahwa soal tersebut cukup mudah dipahami, dan cukup mudah dikerjakan. Pada soal dengan kategori tidak valid dan tetap tidak valid, siswa banyak menemui kendala saat mengerjakan soal tersebut, di antaranya: (1) kurang memahami konsep Gerak Lurus, terutama pada benda dikatakan bergerak atau tidak bergerak terhadap titik acuan tertentu; (2) kurang memahami konsep grafik; (3) terpaku pada rumus atau terbiasa menghafalkan rumus sehingga mereka tidak dapat memecahkan soal dengan berbagai cara. Pada soal kategori valid menjadi tidak valid, siswa mengungkapkan bahwa untuk soal tipe matematis, mereka terpaku pada rumus instan yang sudah ada, sehingga mereka hanya memberikan jawaban hanya menggunakan satu cara sesuai dengan rumus yang mereka ketahui.

Tabel 1. Hasil Uji Validitas pada Uji Coba Produk

\begin{tabular}{|c|c|c|c|c|}
\hline Tahap & Kriteria & Nomor Butir Soal & Jumlah & $\begin{array}{c}\text { Persentase } \\
(\%)\end{array}$ \\
\hline \multirow{2}{*}{$\begin{array}{l}\text { Uji Coba } \\
\text { Produk }\end{array}$} & Valid & $\begin{array}{c}1,5,7,11,13,14,15,18 \\
20,21,22,24,25,26,28 \\
30,31,33,34,35,36\end{array}$ & 21 & 58,33 \\
\hline & Tidak Valid & $\begin{array}{c}2,3,4,6,8,9,10,12,16 \\
17,19,23,27,29,32\end{array}$ & 15 & 41,67 \\
\hline \multirow[t]{2}{*}{$\begin{array}{c}\text { Uji Coba } \\
\text { Pemakaian }\end{array}$} & Valid & $\begin{array}{c}1,2,5,6,7,11,12,13, \\
14,15,16,18,20,21,22, \\
25,27,29,30,31,32,33, \\
34,35,36\end{array}$ & 25 & 69,44 \\
\hline & Tidak Valid & $\begin{array}{c}3,4,8,9,10,17,19,23 \\
24,26,28\end{array}$ & 11 & 30,56 \\
\hline
\end{tabular}

Banyak siswa yang tidak memberikan jawaban maupun memberikan jawaban yang kurang tepat. Selain itu, respons siswa terhadap instrumen yang disusun menunjukkan bahwa waktu pengerjaan soal yang diberikan tidak cukup. Hal ini sesuai dengan pendapat Fitriatun (2016) yang menyatakan bahwa valid tidaknya suatu soal disebabkan oleh beberapa faktor, salah satunya adalah banyak soal yang dianggap sukar oleh siswa dan pembatasan waktu dalam mengerjakan soal. Butir soal yang dinyatakan valid selanjutnya didokumentasikan dalam bank soal dan dapat digunakan lagi pada tes yang akan datang. 


\section{Reliabilitas}

Berdasarkan

perhitungan reliabilitas soal, diperoleh hasil 0,877 pada uji coba produk dan 0,879 pada uji coba pemakaian. Hasil analisis reliabilitas masuk pada kategori sangat tinggi. Instrumen asesmen yang disusun merupakan instrumen asesmen yang berkualitas sangat baik dari segi reliabilitasnya.

\section{Tingkat Kesukaran}

Analisis tingkat kesukaran butir soal pada uji coba produk dan uji coba pemakaian dapat dilihat pada Tabel 2. Berdasarkan hasil analisis butir soal, proporsi taraf kesukaran soal belum ideal. Proporsi tingkat kesukaran soal yang baik menurut Arifin (2009) yaitu soal sukar 25\%, soal sedang $50 \%$, dan soal mudah $25 \%$ (1: $2: 1)$. Hasil angket respons siswa menunjukkan beberapa faktor yang mempengaruhi hasil analisis taraf kesukaran butir soal, di antaranya: (1) siswa tidak dapat menangkap maksud soal, (2) siswa lupa rumus, (3) siswa tidak terbiasa dengan soal berpikir kreatif, dan (4) siswa tidak terbiasa dengan soal multi representasi.

Tabel 2. Hasil Analisis Tingkat Kesukaran

\begin{tabular}{|c|c|c|c|c|}
\hline Tahap & Kriteria & Nomor Butir Soal & Jumlah & $\begin{array}{c}\text { Persentase } \\
(\%)\end{array}$ \\
\hline \multirow{5}{*}{$\begin{array}{l}\text { Uji Coba } \\
\text { Produk }\end{array}$} & Terlalu Sukar & - & - & - \\
\hline & Sukar & $\begin{array}{c}1,2,3,4,5,6,8,9,10 \\
11,12,14,15,16,17 \\
18,23,25,27,29,32\end{array}$ & 21 & 58,33 \\
\hline & Cukup/Sedang & $\begin{array}{c}7,13,19,20,21,22,24 \\
26,28,30,31,33,34 \\
35,36\end{array}$ & 15 & 41,67 \\
\hline & Mudah & - & - & - \\
\hline & Terlalu Mudah & - & - & - \\
\hline \multirow{5}{*}{$\begin{array}{l}\text { Uji Coba } \\
\text { Pemakaian }\end{array}$} & Terlalu Sukar & - & - & - \\
\hline & Sukar & $\begin{array}{c}11,12,14,15,16,20 \\
25,27,29,31,32,34, \\
35,36\end{array}$ & 14 & 56 \\
\hline & Sedang/Cukup & $\begin{array}{c}1,2,5,6,7,13,18,21 \\
22,30,33\end{array}$ & 11 & 44 \\
\hline & Mudah & - & - & - \\
\hline & Terlalu Mudah & - & - & - \\
\hline
\end{tabular}

\section{Daya Beda}

Analisis daya beda butir soal pada uji coba produk dan uji coba pemakaian dapat dilihat pada Tabel 3. Soal dapat memiliki daya beda yang jelek atau sangat jelek, karena soal tersebut merupakan soal yang 
sukar sehingga siswa hanya melakukan guessing dalam menjawab (Fitriatun \& Sukanti, 2016). Analisis data yang dilakukan menunjukkan soal yang memiliki daya beda pada kategori jelek atau sangat jelek memiliki taraf kesukaran pada kategori sukar.
Tindak lanjut terhadap hasil analisis taraf kesukaran dan daya beda menurut Sudijono (2015) adalah mendokumentasikan soal yang sudah baik ke dalam bank soal, dan membuang soal yang tidak baik atau direvisi.

Tabel 3. Hasil Analisis Daya Beda

\begin{tabular}{|c|c|c|c|c|}
\hline Tahap & Kriteria & Nomor Butir Soal & Jumlah & $\begin{array}{l}\text { Persentase } \\
(\%)\end{array}$ \\
\hline \multirow{5}{*}{$\begin{array}{l}\text { Uji Coba } \\
\text { Produk }\end{array}$} & Sangat Baik & - & - & - \\
\hline & Baik & $20,21,33$ & 3 & 8,34 \\
\hline & Cukup & $\begin{array}{c}5,7,13,14,18,24,31 \\
35\end{array}$ & 8 & 22,22 \\
\hline & Jelek & $\begin{array}{c}1,3,4,6,8,9,10,11 \\
12,15,17,22,23,25 \\
26,27,28,30,32,34,36\end{array}$ & 21 & 58,33 \\
\hline & Sangat Jelek & $2,16,19,29$ & 4 & 11,11 \\
\hline \multirow{5}{*}{$\begin{array}{l}\text { Uji Coba } \\
\text { Pemakaian }\end{array}$} & Sangat Baik & - & - & - \\
\hline & Baik & $1,2,6,21,22,29,33,35$ & 8 & 32 \\
\hline & Cukup & $\begin{array}{c}7,11,13,14,15,18,20 \\
27,31,34 \\
\end{array}$ & 10 & 40 \\
\hline & Jelek & $5,12,16,25,30,32,36$ & 7 & 28 \\
\hline & Sangat Jelek & - & - & - \\
\hline
\end{tabular}

Contoh soal representasi verbal ditunjukkan pada Gambar 1a tentang gerak sebuah pesawat dari mulai lepas landas sampai berhenti. Keterampilan abad ke-21 yang dipakai adalah berpikir kreatif yang menuntut siswa untuk dapat memberikan detail-detail informasi pada teks (berpikir elaborasi). Contoh jawaban siswa dapat dilihat pada Gambar 1b dan Gambar 1c.
Pada Gambar 1b, siswa menjawab secara detail semua jenis gerak yang diinformasikan dalam teks; sedangkan pada Gambar 1c siswa cenderung tidak mengerti maksud dari soal. Siswa menjawab soal dengan kebiasaan yang diajarkan oleh guru, yaitu menulis apa yang diketahui. 
Phy. Educ. Res. J. Vol. 2 No. 1 (2020), 19-34

Bacalah teks berikut dengan saksama!

Sebuah pesawat Boeing 747 lepas landas di Bandara Ahmad Yani menuju Bandara Soekarno Hatta, Jakarta. Setelah kecepatannya mencapai $300 \mathrm{~km} / \mathrm{jam}$, badan pesawat terangkat dan mulai terbang. Kecepatan terus ditambah hingga mencapai $700 \mathrm{~km} / \mathrm{jam}$. Dibutuhkan waktu 15 menit untuk pesawat mulai bergerak hingga kecepatannya mencapai $700 \mathrm{~km} / \mathrm{jam}$. Saat itu kondisi cuaca cerah dan tidak terjadi turbulensi sehingga pesawat terus melaju dengan kecepatan $700 \mathrm{~km} / \mathrm{jam}$. Lima belas menit sebelum landing, pesawat mulai menukik ke bawah dan kecepatannya mulai berkurang. Pada saat kecepatannya mencapai $200 \mathrm{~km} / \mathrm{jam}$, roda pesawat menyentuh landasan. Saat menyentuh landasan, kecepatan pesawat makin lama makin berkurang hingga akhirnya mencapai $40 \mathrm{~km} / \mathrm{jam}$. Dengan kecepatan tersebut, pesawat bergerak menuju tempat parkir. Pesawat diarahkan oleh petugas bandara ke jalur tertentu dan akhirnya berhenti.

Berdasarkan teks di atas, identifikasi jenis gerak yang diinformasikan! Jelaskan!

(a)

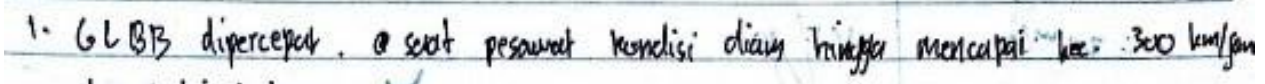
dan mulai terbony

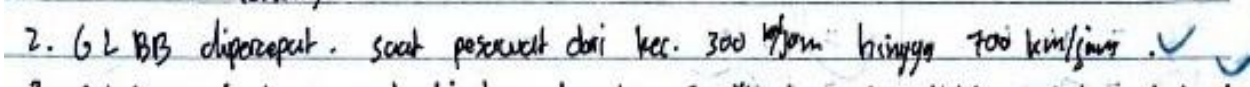

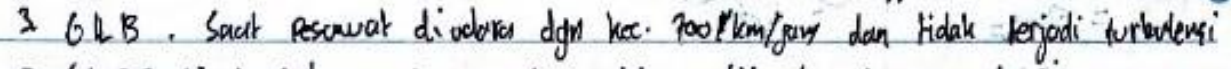

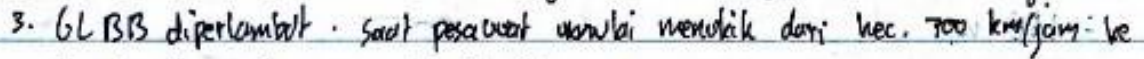
$200 \mathrm{~km} / \mathrm{jam}$ den menyeshm bandaxion $\checkmark$

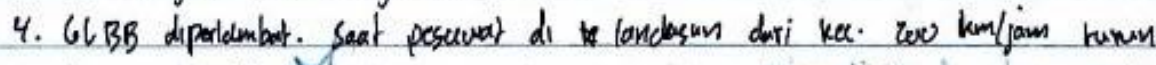
be $40 \mathrm{~km} / \mathrm{jom}$

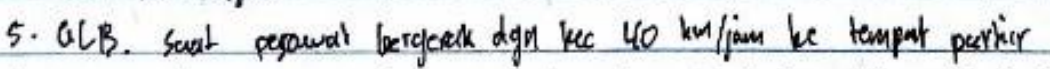

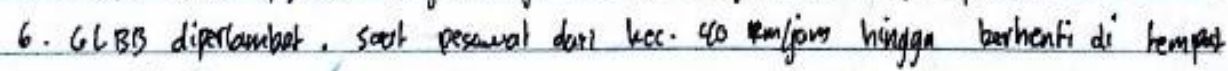
porkir.

(b)

$\left.\begin{array}{rl}\text { Diket : } & v_{0}=300 \mathrm{~km} / \mathrm{sam} \\ v_{t} & : 700 \mathrm{~km} / \mathrm{s}\end{array}\right)$

(c)

Gambar 1. (a) Soal Representasi Verbal, (b) dan (c) Contoh Jawaban Siswa untuk Soal Representasi Verbal 
Perhatikan gambar di bawah ini!

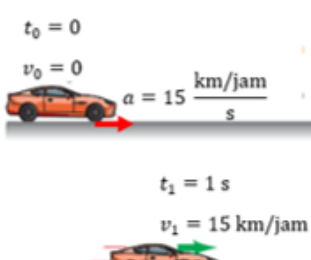

$v_{1}=15 \mathrm{~km} / \mathrm{jam}$

Sumber: Giancoli (2014: 29)

Gambarkan lanjutan gerak mobil tersebut pada interval waktu yang Anda kehendaki!

(a)

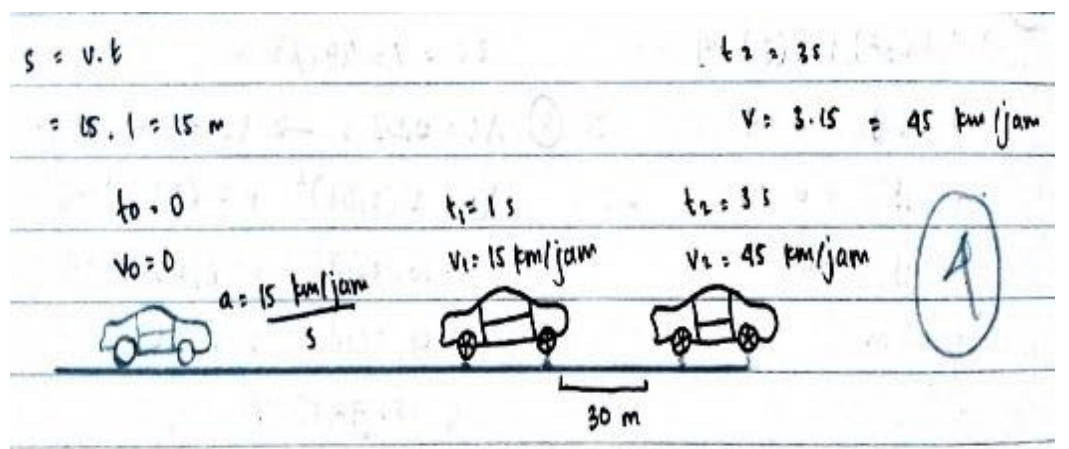

(b)

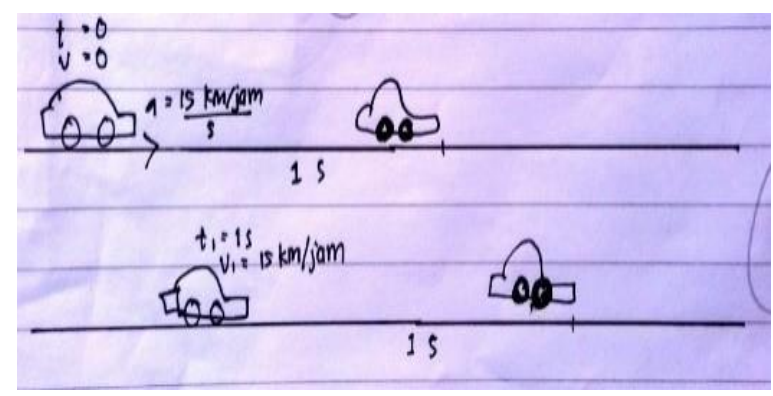

(c)

Gambar 2. (a) Soal Representasi Gambar, (b) dan (c) Contoh Jawaban Siswa untuk Soal Representasi Gambar

Soal representasi gambar dengan percepatan $a$. Kemampuan ditunjukkan pada Gambar 2a berpikir kreatif yang diukur yaitu tentang gerak sebuah mobil dari siswa dituntut untuk dapat keadaan berhenti sampai bergerak memberikan jawaban yang tidak 
seperti biasanya (berpikir original). Contoh jawaban siswa dapat dilihat pada Gambar 2b dan Gambar 2c. Pada Gambar 2b, siswa menggambar lanjutan gerak mobil dengan $t=3 \mathrm{~s}$. Jawaban yang lazim dijawab adalah menggambar lanjutan gerak dengan $t=2 \mathrm{~s}$ atau secara berututan; sedangkan pada Gambar 2c siswa cenderung tidak mengerti maksud dari soal. Siswa menjawab soal dengan hanya menggambar tanpa diberi rincian gambar terkait waktu dan kecepatannya.
Soal representasi matematis ditunjukkan pada Gambar 3a tentang gerak vertikal ke atas. Kemampuan berpikir kreatif yang diukur yaitu siswa dituntut untuk dapat memberikan jawaban dengan banyak cara (berpikir luwes). Contoh jawaban siswa dapat dilihat pada Gambar 3b dan Gambar 3c. Pada Gambar 3b siswa menjawab dengan dua cara berbeda dan benar; sedangkan pada Gambar 3c siswa menjawab soal hanya dengan satu cara dan salah.

Sebuah bola dilempar vertikal ke atas dengan kecepatan $15 \mathrm{~m} / \mathrm{s}$. Berapa ketinggian maksimum yang dicapai bola tersebut? Hitung menggunakan beberapa cara berbeda! $\left(g=10 \mathrm{~m} / \mathrm{s}^{2}\right)$

(a)

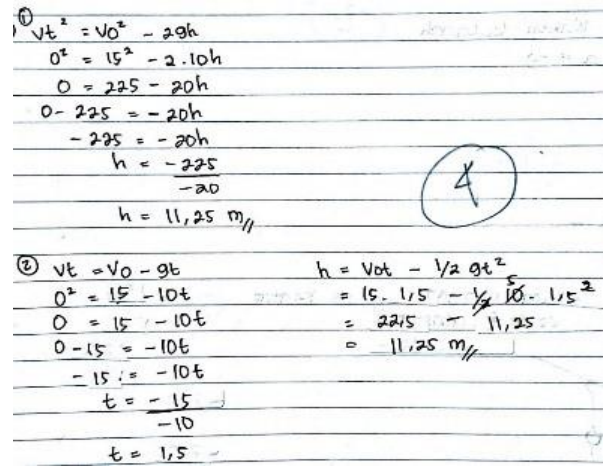

(b)

Jawab
$\begin{aligned} V_{x^{2}} & =V_{0}^{2}+2 g h \\ 0^{2} & =15^{2}+2 \cdot 10 \cdot h \\ 0 & =25+20 h \\ h & =45\end{aligned}$

(c)

Gambar 3. (a) Soal Representasi Matematis, (b) dan (c) Contoh Jawaban Siswa untuk Soal Representasi Matematis 
Soal representasi grafik satuan yang sesuai, besar dan arah ditunjukkan Gambar 4a tentang percepatan yang ditambahkan gerak jatuh bebas. Kemampuan pada gambar sesuai dengan besar berpikir kreatif yang diukur yaitu dan arah percepatan gravitasi, dan siswa dituntut untuk dapat grafik yang digambar benar; memberikan jawaban yang tidak sedangkan pada Gambar 4c siswa seperti biasanya (berpikir original). cenderung hanya menggambar Contoh jawaban siswa dapat dilihat pada Gambar 4b dan Gambar 4c. Pada Gambar 4b siswa menggambar grafik secara lengkap dari mulai besaran pada setiap sumbunya yang dilengkapi dengan tanpa diberi rincian gambar seperti satuan besaran waktu dan besar percepatan yang tidak ada pada grafik. Grafik yang digambar juga salah.

Seekor monyet menjatuhkan buah dari pohon di mana gerakan buah jatuh memenuhi grafik berikut.

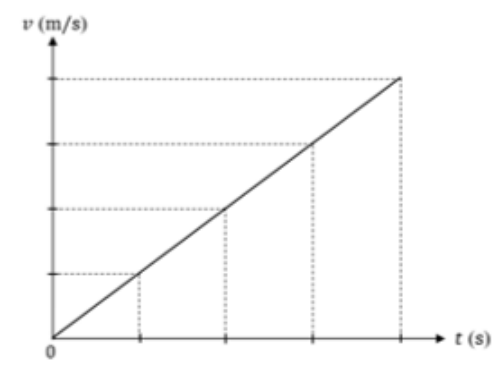

Buatlah grafik yang menunjukkan percepatan gerak buah jatuh sesuai grafik di atas!

(a)

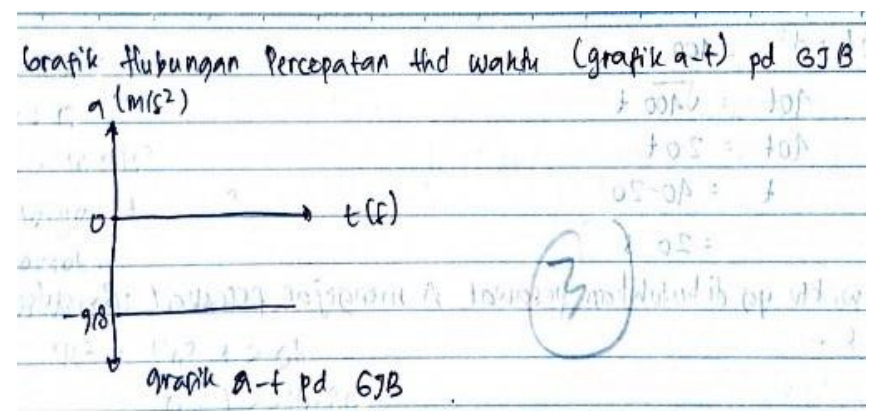

(b) 


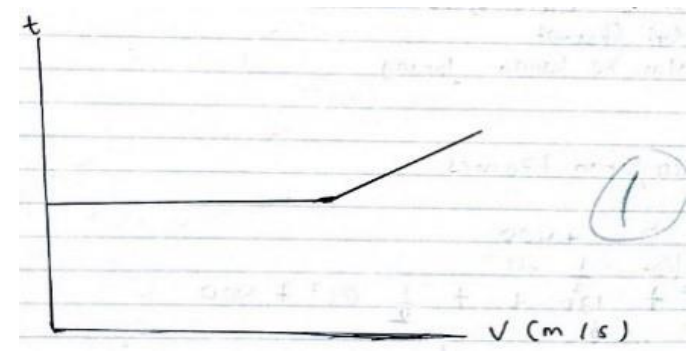

(c)

Gambar 4. (a) Soal Representasi Grafik, (b) dan (c) Contoh Jawaban Siswa untuk Soal Representasi Grafik

\section{KESIMPULAN}

Produk yang dihasilkan pada penelitian ini berupa instrument asesmen multi representasi pada materi Gerak Lurus. Hasil analisis menunjukkan instrumen yang dikembangkan valid dan reliabel. Butir soal valid berjumlah $69,44 \%$ dari seluruh soal yang diujikan; dengan $56 \%$ soal sukar dan $44 \%$ soal sedang. Daya beda soal terdiri atas $32 \%$ baik, $40 \%$ cukup, dan $28 \%$ jelek.

\section{UCAPAN TERIMA KASIH}

Keberhasilan penyusunan paper ini tidak terlepas dari peran, dukungan, dan bantuan dari berbagai pihak. Oleh karena itu, penulis mengucapkan terima kasih kepada:

1. Prof. Dr. Fathur Rokhman, M.Hum., Rektor Universitas Negeri Semarang,

2. Prof. Dr. Sudarmin, M.Si., Dekan Fakultas Matematika dan Ilmu
Pengetahuan Alam Universitas Negeri Semarang,

3. Dr. Suharto Linuwih, M.Si., Ketua Jurusan Fisika Fakultas Matematika dan Ilmu Pengetahuan Alam Universitas Negeri Semarang,

4. Kepala SMA Negeri 7 Semarang, SMA Negeri 9 Semarang, SMA Negeri 1 Banyumas, SMA Negeri 1 Gombong, SMA Negeri 1 Sumpiuh, dan MA Negeri 3 Banyumas yang telah memberikan izin penelitian,

5. Guru fisika SMA Negeri 7 Semarang, SMA Negeri 9 Semarang, SMA Negeri 1 Banyumas, SMA Negeri 1 Gombong, SMA Negeri 1 Sumpiuh, dan MA Negeri 3 Banyumas yang telah memberikan bimbingan selama melakukan penelitian,

6. Siswa kelas X SMA Negeri 7 Semarang, SMA Negeri 9 Semarang, SMA Negeri 1 Banyumas, SMA Negeri 1 Gombong, SMA Negeri 1 
Sumpiuh, dan MA Negeri 3 Banyumas yang telah berpartisipasi dengan sangat baik pada proses penelitian,

7. Semua pihak yang telah membantu dalam penyelesaian paper ini yang tidak dapat saya sebutkan satu persatu.

\section{DAFTAR PUSTAKA}

Alwi. 2015. Kriteria Empirik dalam Menentukan Ukuran Sampel pada Pengujian Hipotesis Statistika dan Analisis Butir. J. Formatif, 2(2), 140-148.

Arifin, Z. 2009. Evaluasi Pembelajaran. Bandung: Remaja Rosdakarya.

Brookhart, S. M. 2010. How to assess higher-order thinking skills in your classroom. Alexandria, Virginia USA: ASCD.

Fitriatun, A. and S. 2016. Analisis Validitas, Reliabilitas, dan Butir Soal Latihan Ujian Nasional Ekonomi Akuntansi di MAN Maguwoharjo. J. Kajian Pendidikan Akuntansi Indonesia, 5(8), 1-11.

Gunel, M. et al. 2006. Comparing Student Understanding of Quantum Physics When Embedding Multimodal Representations into Two Different Writing Formats: Presentation Formaat Versus Summary Report Format. J. Science Educ., 90(6), 1092-1112.

Hariyanto, I. B. . 2014. Asesmen Pembelajaran. Bandung: PT. Remaja Rosdakarya.
Leksana, K. G. 2017. Pengembangan Instrumen Tes Multi Rrepresentasi pada Konsep Alatalat Optik untuk Mengidentifikasi Kemampuan Representasi Siswa. Univ. Islam Negeri Syarif Hidayatullah, Jakarta.

Misel and E. Suwangsih. 2016. Penerapan Pendekatan Matematika Realistik untuk Meningkatkan Kemampuan Representasi Matematis Siswa. J. Metodi DIdaktik, 10(2), 27-36. Munandar, U. 2012. Pengembangan Kreativitas Anak Berbakat. Jakarta: Rineka Cipta.

Osman, K. et al. 2010. Development and Validation of The Malaysian 21st Century Skills Instrument (M-21CSI) for Science Students. Proc. Social and Behavioral Sciences, 9, 599603.

Purwanti, A. et al. 2017. Penguasaan Konsep Materi Kinematika pada Siswa SMA Kelas X dengan Menggunakan Pembelajaran

Multirepresentasi.

Pendidikan: Teori, Penelitian, Dan Pengembangan, 2(4), 75578.

Purwanti, A. et al. 2016. Penguasaan Konsep dan Kemampuan Representasi Materi Gerak Lurus Siswa SMA Kelas XII,. Proc. Seminar Nasional Pendidikan IPA, 1.

Rusilowati, A. 2006. Profil Kesulitan Belajar Fisika Pokok Bahasan Kelistrikan Siswa 
SMA di Kota Semarang. J. Pendidikan Fisika Indonesia, 4(2), 100-106.

Sinaga. 2014. The Effectiveness Of Learning To Represent Physics Concept Appoarch: Preparing Pre-Service Physics Teachers To Be Good Teachers. International Journal of Research in Applied, Natural and Social Sciences, 2.

Sudijono, A. 2015. Pengantar Evaluasi Pendidikan. Jakarta: PT Raja Grafindo Persada.

Sugiyono. 2017. Metode Penelitian Kuantitatif, Kualitatif, dan RED.
Bandung: INA: Alfabeta.

Sunyono. 2015. Supporting Students in Learning with Multiple Representation to Improve Student Mental Models on Atomic Structures Concepts. Electronic Journal of Science Education International, 2.

Susianna, N. 2014. Implementasi Keterampilan Abad 21 dalam Kurikulum 2013. Proc. Seminar Nasional Pendidikan Matematika Sains, Dan Tik. 
Phy. Educ. Res. J. Vol. 2 No. 1 (2020), 19-34 